Accepted Date : 09 - 06-2021, Publish Date : 16-06-2021 Vol 01. Issue 01

\title{
Analysis And Design Of Information System Report Of Medical Check Up In Chio Medical Center Clinic Web-Based
}

\author{
Apit Priatna $^{\mathrm{a} *}$, Yahya Suherman $^{\mathrm{b}}$, Indaryono $^{\mathrm{c}}$, Diany Anggrainy $^{\mathrm{d}}$ \\ a, b,c,d STMIK Rosma, Jl. Kertabumi No. 62, Karawang 41311, Indonesia \\ *Corresponding author: apit.priatna@dosen.rosma.ac.id
}

\begin{abstract}
Chio Medical Center is one of the services in the health sector that is engaged in special medical check-ups for prospective employees who will work and permanent employees in a company. Currently, the system that processes medical check-up report data has not been computerized properly, so that data or files are stored conventionally and it is difficult to find the required data. The research method used in this study is the System Development Life Cycle (SDLC) method and system development using the Waterfall model which starts from analysis and observation of the system running in the company. The results of the observations show that the system that runs at the Chio Medical Center clinic has not been computerized properly, namely in recording examination reports using excel and word files so that they have not been stored in a structured database. This system is designed using the Dreamweaver application as a web-based editor tool and uses the PHP and MySQL programming languages as the database. The result of this research is a web-based medical check-up report information system which is expected to assist employees in inputting data and improve the process of providing information services to clients so that it is faster and more accurate.
\end{abstract}

Keywords : Clinic; Medical Check Up; MySQL; PHP; SDLC

\begin{abstract}
Abstrak
Chio Medical Center merupakan salah satu jasa pelayanan dalam bidang kesehatan yang begerak dalam bidang pemeriksaan khusus medical check up bagi calon karyawan yang akan bekerja dan karyawan tetap pada sebuah perusahaan. Saat ini sistem yang mengolah data laporan hasil pemeriksaan medical check up belum terkomputerisasi dengan baik, sehingga dalam penyimpanan data atau berkas secara konvensional dan sulitnya mencari data yang dibutuhkan. Metode penelitian yang digunakan dalam penelitian ini adalah metode System Development Life Cycle (SDLC) dan pengembangan sistem menggunakan model Waterfall yang dimulai dari analisis dan observasi terhadap sistem yang berjalan di perusahaan. Hasil observasi menunjukan bahwa sistem yang berjalan di klinik Chio Medical Center belum terkomputerisasi dengan baik yaitu dalam pencatatan laporan pemeriksaan menggunakan file excel dan word sehingga belum tersimpan di database secara terstruktur. Sistem ini dirancang dengan menggunakan aplikasi Dreamweaver sebagai tools editor berbasis web dan menggunakan bahasa pemograman PHP dan MySQL sebagai database. Hasil dari penelitian ini adalah sebuah sistem informasi laporan pemeriksaan medical check up berbasis web yang diharapkan dapat membantu karyawan dalam menginput data dan meningkatkan proses layanan informasi terhadap klien sehingga lebih cepat dan akurat.
\end{abstract}

Keywords : Klinik; Medical Check Up; MySQL; PHP; SDLC

\section{Pendahuluan}

Berkembangnya teknologi informasi, meningkatkan akan kebutuhan teknologi informasi di seluruh bidang kehidupan. Kebutuhan masyarakat menuntut adanya teknologi informasi yang mudah dipahami dan dapat digunakan oleh semua user serta membuat pekerjaan yang dihasilkan menjadi lebih efektif dan efisien. 
Chio Medical Center yang berlokasi di Jalan Arteri Tol Karawang Barat Ruko Karaba Indah No. 7, Desa Wadas, Kecamatan Teluk Jambe Timur, Kabupaten Karawang adalah salah satu penyedia pelayanan kesehatan yang khususnya bergerak dalam medical check up untuk sebuah perusahaan. Medical check up merupakan pemeriksaan yang lebih difokuskan pada upaya pencegahan primer dan sekunder, yaitu mendeteksi berbagai faktor kesehatan secara menyeluruh yang dapat menimbulkan penyakit tertentu di kemudian hari. Pelayanan medical check up di Chio Medical Center lebih difokuskan kepada sebuah perusahaan yang akan mencari calon karyawan baru dan untuk medical check up rutin bagi karyawan tetap yang dilaksanakan dalam satu tahun sekali. Pelayanan kesehatan yang tersedia di Chio Medical Center tidak hanya untuk perusahaan saja tetapi untuk masyarakat umum dapat juga menggunakan pelayanan kesehatan yang tersedia.

Pencatatan laporan hasil pemeriksaan medical check up di Chio Medical Center masih menggunakan microsoft word dan microsoft excel sehingga belum terkomputerisasi dengan baik. Hasil dari medical check up akan dikirim ke perusahaan yang bersangkutan berupa berkas laporan. Jumlah pasien dalam satu hari bisa mencapai \pm 100 pasien dan perusahaan yang bekerjasama dengan Chio Medical Center berjumlah \pm 60 perusahaan. Hasil dari medical check up calon karyawan digunakan oleh perusahaan sebagai pendukung keputusan penerimaan karyawan baru dengan tujuan untuk mengetahui riwayat kesehatan karyawan sebelum diterima kerja, sedangkan hasil dari medical check up tahunan atau rutin yang dilaksanakan satu tahun sekali berfungsi untuk mengecek kesehatan para pekerja. Isi dari laporan hasil pemeriksaan medical check up meliputi pemeriksaan laboratorium yaitu pemeriksaan darah, urine, visus mata, tinggi badan, berat badan, tensi, buta warna, rontgen paru, serta pemeriksaan fisik oleh dokter umum adapun pemeriksaan tambahan yaitu audio (test pendengaran), spiro (test pernapasan) dan ekg (rekam jantung) dan kesimpulan dari hasil medical check up yang menjadi penentuan calon karyawan untuk diterima kerja.

Proses laporan hasil pemeriksaan medical check up diawali dengan pencatatan identitas pasien oleh receptionist, kemudian pasien akan mendapatkan kartu peserta medical. Kemudian pasien akan melakukan proses medical check up mulai dari pengambilan darah dan urine serta pemeriksaan fisik. Setelah pasien selesai melakukan proses medical, dilakukan pencatatan hasil dari medical chek up secara komputerisasi oleh petugas. Dalam proses pembuatan hasil medical check up yang dilakukan oleh petugas masing-masing bagian dan untuk merekap hasil pemeriksaan dengan menggunakan file excel dan word sehingga penyimpanan yang belum terstruktur dengan menggunakan database.

Beberapa penelitian terdahulu yang melakukan analisis dan perancangan sebuah sistem informasi berbasis web mengatakan bahwa perancangan sistem informasi berbasis web mampu meningkatkan efektifitas dan efisiensi dalam pembuatan laporan suatu perusahaan, diantaranya adalah penelitian yang dilakukan oleh Yulistyawan (2017) [1] yang merancang Sistem Penjadwalan Medical Check Up PT. PAL Indonesia-Ujung Surabaya dengan menggunakan teknologi berbasis web dan penelitian yang dilakukan oleh Gunawan et al. (2020) [2] yang juga merancang Sistem Informasi Medical Check Up Guna Mempercepat Pelayanan MCU di RSUD Brebes.

Berdasarkan permasalahan dan penelitian terdahulu di atas, maka dibutuhkan suatu sistem baru yang dapat memperbaiki kegiatan tersebut dengan memanfaatkan fasilitas komputer yang terdapat di Chio Medical Center. Dimana sistem yang baru tersebut dapat mempermudah kinerja setiap bagian dalam melakukan pengolahan data laporan pemeriksaan medical check up dan bagi pihak perusahaan dapat melihat hasil dari medical check up secara online melalui website yang disediakan. Selain itu, diharapkan dalam penyimpanan database menjadi terstruktur dan aman.

\section{Tinjauan Pustaka}

\subsection{Sistem Informasi}

Sistem informasi adalah suatu sistem di dalam suatu organisasi yang mempertemukan kebutuhan pengolahan transaksi harian, mendukung operasi, bersifat manajerial dan kegiatan strategi dari suatu organisasi yang menyediakan pihak luar tertentu dengan laporan-laporan yang diperlukan [3].

Menurut pendapat Laudon dan Laudon (2013:47) sistem informasi dapat didefinisikan sebagai serangkaian komponen yang saling berhubungan yang mengumpulkan (atau mendapatkan), memproses, menyimpan, dan mendistribusikan informasi yang mendukung pengambilan keputusan dan pengawasan di dalam sebuah organisasi [4].

Berdasarkan definisi sistem informasi diatas dapat disimpulkan, sistem informasi adalah kumpulan dari beberapa sistem di dalam suatu organisasi yang mengumpulkan, memproses, menyimpan dan 
mendistribusikan informasi yang diolah menjadi suatu informasi yang bermanfaat sebagai pendukung pengambilan keputusan dan pengendalian dalam organisasi.

\section{2. $\quad$ PHP}

PHP adalah salah satu server side yang dirancang khusus untuk aplikasi web. PHP disisipkan diantara bahasa HTML dan karena bahasa server side, maka bahasa PHP akan dieksekusi di server, sehingga yang dikirimkan ke browser adalah hasil jadi dalam bentuk HTML, dan kode PHP tidak akan terlihat. PHP termasuk Open Source Product. Jadi, dapat diubah source code dan mendistribusikanya secara bebas [5].

PHP merupakan bahasa pemrograman yang ditujukan untuk membuat program website dimana kode program yang telah dibuat di kompilasi dan dijalankan pada sisi server untuk menghasilkan halaman website yang dinamis. Pada awalnya PHP didirikan untuk Personal Home Page. Karena memilika banyak manfaat dan dapat berkembang dengan baik maka PHP disebut dengan Hypertext Preprocessor [6].

\section{3. $M y S Q L$}

MySQL merupakan software RDMS (Relational Database Management System) yang dapat mengelola database dengan sangat cepat, dapat menampung data dalam jumlah sangat besar, dapat diakses oleh banyak pengguna dan dapat melakukan suatu proses secara sinkron atau bersamaan [7].

Wahana Komputer (2010) dalam [8] MySQL adalah sebuah implementasi dari sistem manajemen basisdata relasional (RDBMS) yang didistribusikan secara gratis. Setiap pengguna dapat secara bebas menggunakan MySQL, namun dengan batasan perangkat lunak tersebut tidak boleh dijadikan produk turunan yang bersifat komersial. MySQL sebenarnya merupakan turunan salah satu konsep utama dalam basisdata yang telah ada sebelumnya; SQL (Structured Query Language). SQL adalah sebuah konsep pengoperasian basisdata, terutama untuk pemilihan atau seleksi dan pemasukan data, yang memungkinkan pengoperasian data dikerjakan dengan mudah secara otomatis.

\subsection{Web}

World Wide Web (WWW) atau sering disebut Web merupakan salah satu sumber daya internet yang berkembang pesat. Informasi Web didistribusikan dengan pendekatan hyperlink yang memungkinkan seseorang memeperoleh informasi dengan meloncat dari satu halaman ke halaman lain [9].

Web adalah satu aplikasi yang berisikan dokumen-dokumen multi media (teks, gambar, video, suara, animasi) di dalamnya yang menggunakan protokol HTTP (hypertext transfer protocol) dan untuk mengaksesnya menggunakan perangkat lunak yang disebut browser. Situs web merupakan kumpulan dari halaman web yang sudah dipublikasikan di jaringan internet dan memiliki domain/URL (Uniform Resource Locator) yang dapat diakses semua pengguna internet dengan cara mengetikan alamatnya [10].

\subsection{System Development Life Cycle (SDLC)}

Rosa A.S dan M. Shalahuddin (2016:26) dalam [11], SDLC adalah proses mengembangkan atau mengubah suatu sistem perangkat lunak dengan menggunakan model-model dan metodologi yang digunakan orang untuk mengembangkan sistem-sistem perangkat lunak sebelumnya (berdasarkan best practice atau cara-cara yang sudah teruji baik). Adapun tahapan-tahapan yang ada pada SLDC secara global adalah sebagai berikut [11]:

\section{a. Inisiasi (initiation)}

Tahap ini biasanya ditandai dengan pembuatan proposal proyek perangkat lunak. Pengembangan konsep sistem (system concept development) Mendefinisikan lingkup konsep termasuk dokumen lingkup sistem, analisa manfaat biaya, manajemen rencana, dan pembelajaran kemudahan sistem.

b. Perencanaan (planning)

Mengembangkan rencana manajemen proyek dan dokumen perencanaan lainnya. Menyediakan dasar untuk mendapatkan sumber daya (resources) yang dibutuhkan untuk memperoleh solusi.

c. Analisa kebutuhan (requirements analysis)

Menganalisis kebutuhan pemakai sistem perangkat lunak (user) dan mengembangkan kebutuhan user. Membuat dokumen kebutuhan fungsional. 
d. Desain (design)

Mentransformasikan kebutuhan detail menjadi kebutuhan yang sudah lengkap, dokumen desain sistem fokus pada bagaimana dapat memenuhi fungsi-fungsi yang dibutuhkan.

e. Pengembangan (development)

Mengonversi desain ke sistem informasi yang lengkap termasuk bagaimana memperoleh dan melakukan instalasi lingkungan sistem yang dibutuhkan, membuat basis data dan mempersiapkan prosedur kasus pengujian, mempersiapkan berkas atau file pengujian, pengkodean, pengompilasian, memperbaiki dan membersihkan program serta peninjauan pengujian.

f. Integrasi dan pengujian (integration and test)

Mendemonstrasikan sistem perangkat lunak bahwa telah memenuhi kebutuhan yang dispesifikasikan pada dokumen kebutuhan fungsional. Dengan siarahkan oleh staf penjamin kualitas (quality assurance) dan user. Manghasilkan laporan analisis pengujian.

g. Implementasi (implementation)

Termasuk pada persiapan implementasi, Implementasi perangkat lunak pada lingkungan produksi (lingkungan pada user) dan menjalankan resolusi dari peramasalahan yang teridentifikasi dari fase integrasi dan pengujian.

$h$. Operasi dan pemeliharaan (operations andmaintenance).

Mendeskripsikan pekerjaan untuk mengoperasikan dan memelihara sistem informasi pada lingkungan produksi (lingkungan pada user), termasuk implementasi akhir dan masuk pada proses peninjauan.

i. $\quad$ Disposisi (disposition)

Mendeskripsikan aktifitas akhir dari pengembangan sistem dan membangun data yang sebenarnya sesuai dengan aktifitas user.

\section{Metode}

Penelitian ini menggunakan metode pengembangan sistem yang digunakan penulis dalam penelitian ini adalah System Development Life Cycle (SDLC) waterfall yaitu proses pengembangan atau mengubah suatu sistem perangkat lunak dengan menggunakan model-model dan metodologi yang digunakan orang untuk mengembangkan sistemsistem perangkat lunak sebelumnya berdasarkan best pratice atau cara-cara yang sudah teruji dengan baik [12]. Berikut adalah beberapa tahap dalam model waterfall yaitu:

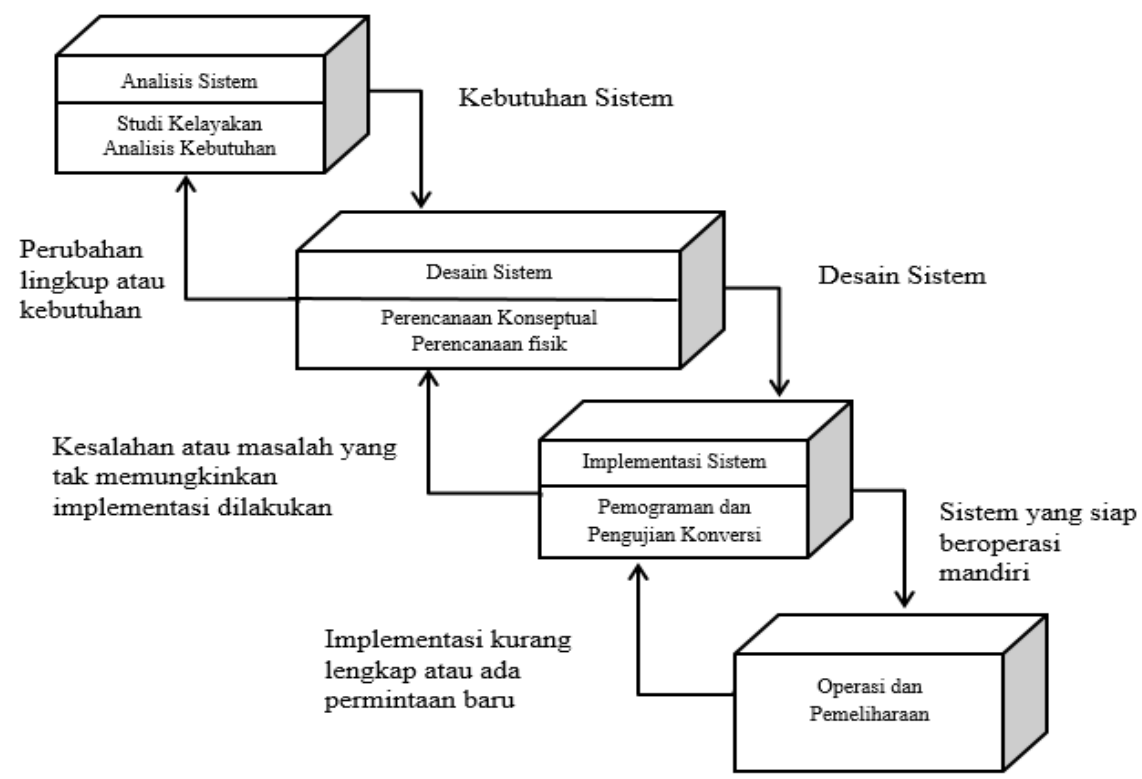

Gambar 1. Tahapan-tahapan dalam SDLC

Sumber: A. Kadir (2014) [12]

\section{Hasil dan Pembahasan}

\subsection{Analisis Fungsional dan Non-Fungsional}


Analisis fungsipnal dan non fungsional dilakukan untuk menjelaskan tentang prosedur yang berjalan di dalam sistem informasi rekam medis pada Chio Medical Center, yaitu:

a. Analisis Fungsional

Analisis fungsional dilakukan untuk memberikan gambaran mengenai sistem atau prosedur laporan hasil pemeriksaan medical check up pada Chio Medical Center.

1) Sistem harus mampu melakukan validasi log in user, yang dimaksud yaitu pada saat user akan mengakses sistem tersebut maka user harus memasukan username dan password yang sudah didaftarkan oleh administrator.

2) Sistem harus dapat memproses data input (simpan, ubah dan hapus). Pada saat sistem melakukan pendataan maka sistem harus dapat melakukan semua proses tersebut (simpan, ubah dan hapus).

3) Sistem harus mengahasilakn data output. Semua data yang dimasukan atau yang tersimpan di database akan dikeluarkan oleh sistem (cetak). Maka sistem harus mampu menghasilkan data keluaran berupa report yang sesuai dengan harapan user.

4) Sistem harus menghasilkan informasi dokumen arsip.

b. Analisis Non-Fungsional

Analisis fungsional mencakup analisis perangkat keras (hardware), perangkat lunak (software) dan analisis pengguna (user). Berikut adalah spesifikasi komputer yang dibutuhkan dibagian administrasi rekam medis:

1) Perangkat Keras (Hardware)

a) Processor minimal Intel ${ }^{\circledR}$ Core i3.

b) Memori minimal RAM 4 GB.

c) Power supply.

d) Monitor LCD 15".

e) Hardisk $500 \mathrm{~GB}$

f) Mouse standar dan keyboard standar.

g) Printer standar

2) Perangkat Lunak (Software)

a) Sistem operasi Windows 10.

b) Design Macromedia Dremaweaver.

c) Web Server XAMPP.

4.2. Perancangan Flow Sistem Usulan

Perancangan prosedur merupakan awal dari pembuatan sistem yang akan dibuat, dimana dapat dilihat prosesproses apa saja yang nantinya diperlukan dalam pembuatan suatu sistem. Prosedur yang diusulkan dalam perancangan dapat dilihat pada gambar dibawah ini. 


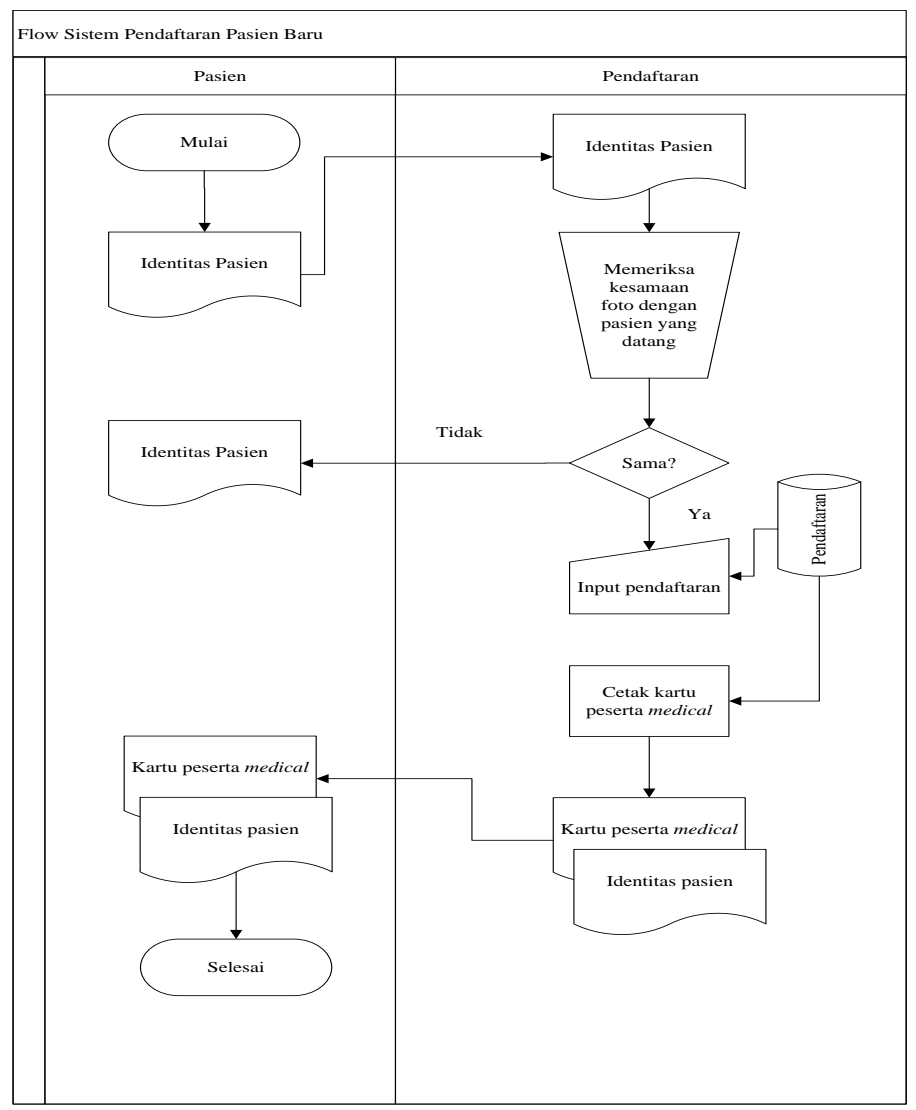

Gambar 2. Flow Sistem Pendaftaran Pasien Baru

a. Pasien : pasien membawa KTP atau identitas lain ke bagian pendaftaran untuk mendapatkan kartu peserta medical.

b. Bagian pendaftaran : menerima KTP atau identitas lain kemudian memeriksa kembali kesamaan photo dengan pasien yang datang. Setelah itu bagian pendaftaran menginput data pasien kedalam database dan mencetak kartu pendaftaran.

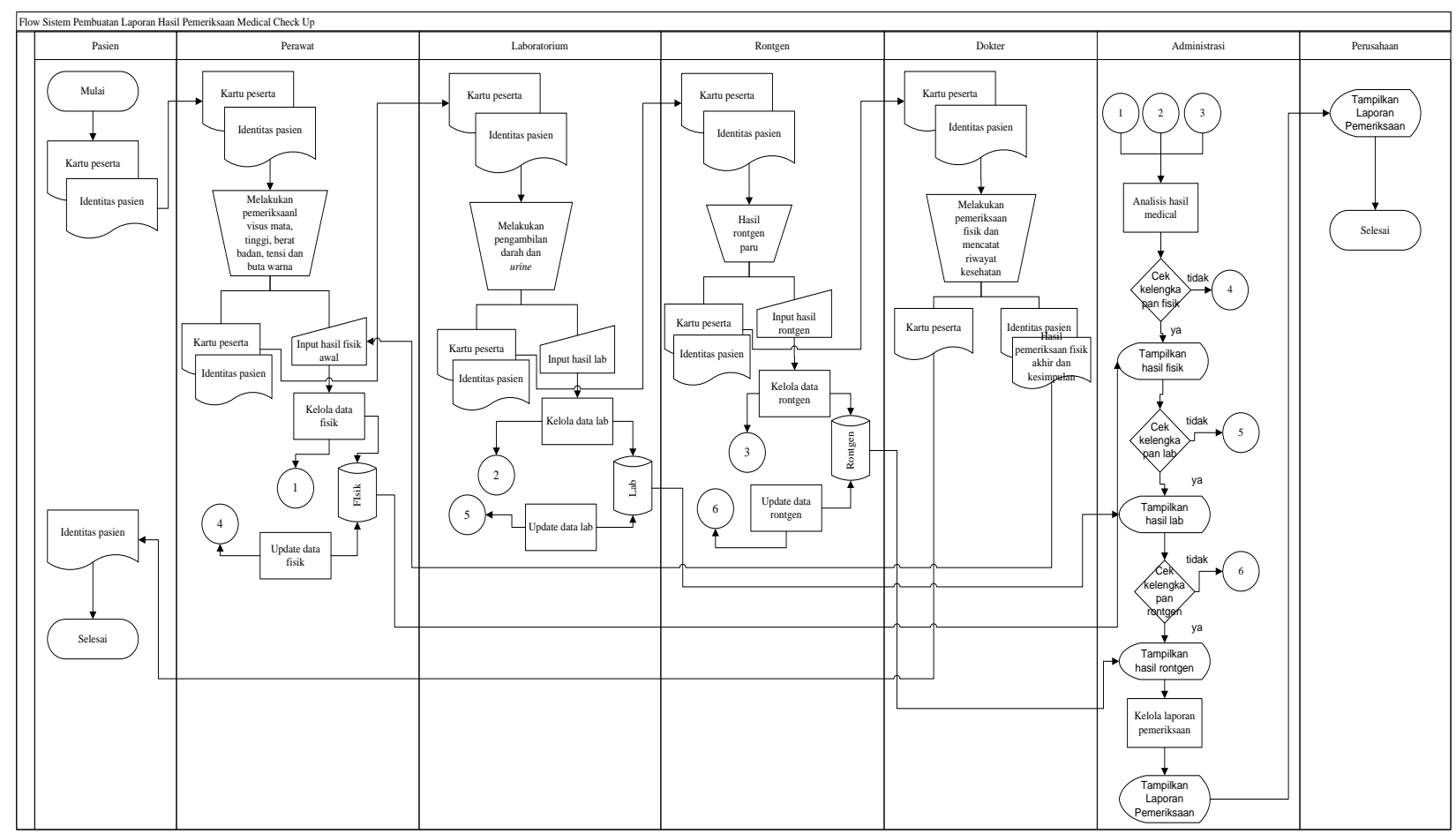

Gambar 3. Flow Sistem Pembuatan Laporan Hasil Pemeriksaan Medical Check Up 
a. Pasien : membawa kartu peserta medical beserta identitas yang kemudian diserahkan kepada bagian laobratorium untuk pengambilan darah dan urine.

b. Laboratorium : melakukan proses pengambilan darah dan urine, setelah selesai kartu peserta dikembalikan kepada pasien. Kemudian petugas lab menginput hasil darah dan urine ke dalam sistem.

c. Perawat : perawat menerima kartu dari pasien kemudian melakukan pemeriksaan tinggi badan, berat badan, visus mata, tensi, nadi dan buta warna. Setlah selesai kartu dikembalikan kepada pasien. Kemudian petugas menginput hasil pemeriksaan di sistem.

d. Radiologi : radiologi menerima kartu dari pasien kemudian melakukan pemeriksaan rontgen paru. Kemudian petigas menginput hasil rontgen di sistem.

e. Dokter : menerima kartu dari pasien, kemudian melakukan pemeriksaan fisik dari ujung kepala sampai kaki, dan menayakan riwayat kesehatan dan penyakit kepada pasien, kemudian mencatat diagnosa penyakit di laporan pemeriksaan fisik. Setelah selesai pemeriksaan, kartu peserta dan laporan hasil pemeriksaan fisik kepada perawat untuk diinput ke dalam sistem. Sedangkan identitas pasien diserahkan kembali kepada pasien.

\subsection{Entity Relationship Diagram (ERD)}

$E R D$ berfungsi untuk menjelaskan hubungan antar data-data dengan basis data. Berikut struktur database dari sistem informasi laporan medical check up pada klinik Chio Medical Center yang telah dikembangkan.

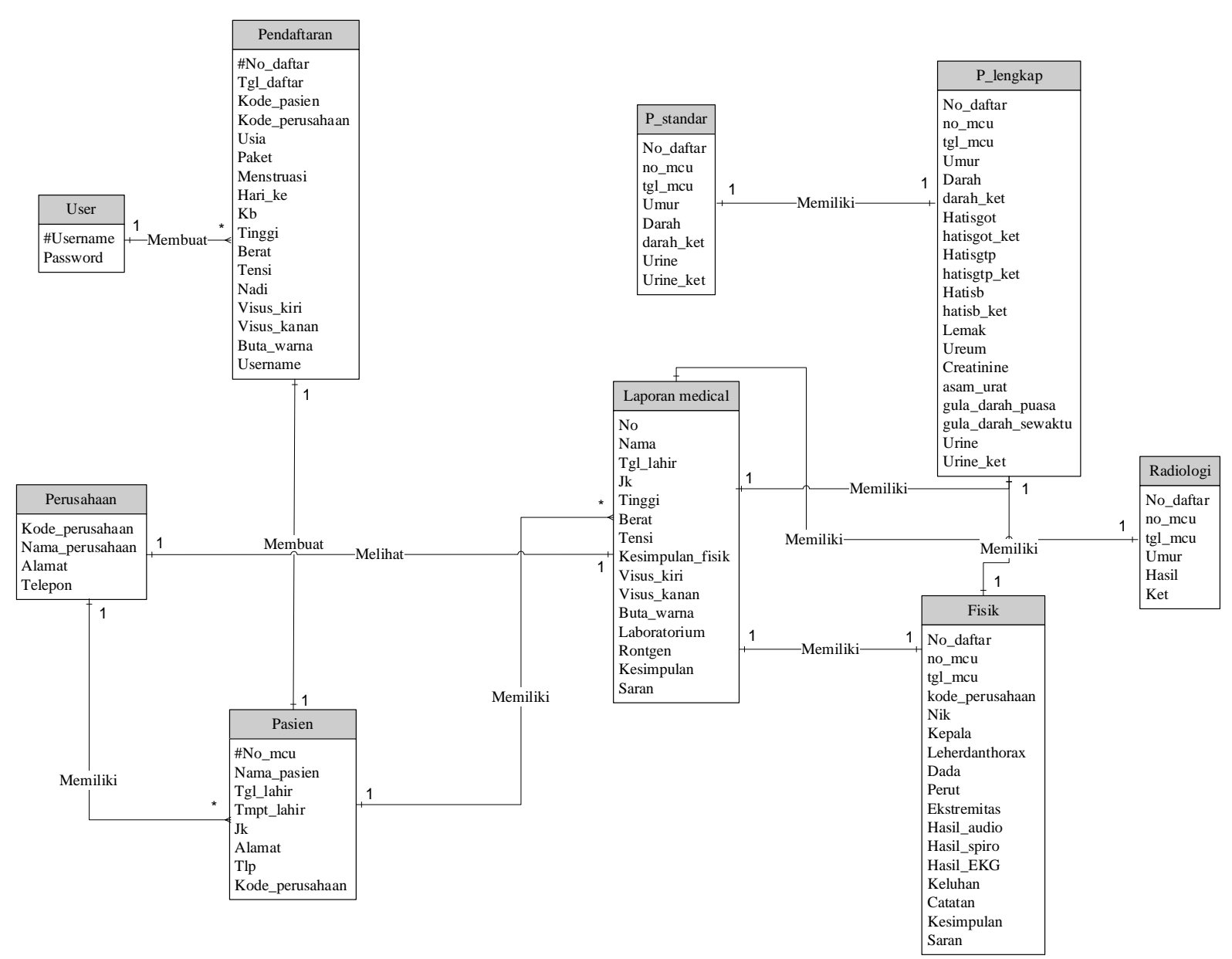

Gambar 4. Entity Relationship Diagram

Berdasarkan ERD diatas, maka dapat dibuah sebuah kamud data. Kamus data berfungsi untuk mendeskripsikan data dan aliran data informasi dari diagram hubungan entity dan dokumendokumen sumber input dari perancangan. 
Tabel 1. Kamus Data

\begin{tabular}{|c|c|c|}
\hline No. & Entitas & Atribut \\
\hline 1. & User & @username+password+nama \\
\hline 2. & Pasien & @no_mcu+nama_pasien+tgl_lahir+tmpt_lahir+jk+alamat+tlp+kode_perusahaan \\
\hline 3. & Perusahaan & @kode_perusahaan+nama_perusahaan+alamat+telepon \\
\hline 4. & Pendaftaran & $\begin{array}{l}\text { @ no_mcu+tgl_mcu+kode_pasien+kode_perusahaan+usia+paket+menstruasi+k } \\
\text { b+tinggi+berat+tensi+nadi+visus_kiri+visus+kanan+buta_warna+username }\end{array}$ \\
\hline 5. & P_standar & @ no_daftar+no_mcu+tgl_mcu+umur+darah+darah_ket+urine+urine_ket \\
\hline 6. & P_lengkap & $\begin{array}{l}\text { no_daftar+no_mcu+tgl_mcu+umur+darah+darah_ket+hatisgot+hatisgot_ket+ha } \\
\text { tisgtp+hatisgtp_ket+hatisb+hatisb_ket+lemak+ureum+creatinine+asam_urat+gu } \\
\text { la_darah_puasa+gula_darah_sewaktu+urine+urine_ket }\end{array}$ \\
\hline 7. & Fisik & $\begin{array}{l}\text { @ no_daftar+no_mcu+tgl_mcu+kode_perusahaan+nik+kepala+leherdanthorax+ } \\
\text { dada+perut+ekstremitas+hasil_audio+hasil_spiro+hasil_EKG+keluhan+catatan } \\
\text { +kesimpulan+saran }\end{array}$ \\
\hline 8. & Radiologi & no_daftar+no_mcu+tgl_mcu+umur+hasil+ket \\
\hline
\end{tabular}

\subsection{Perancangan User Interface}

\subsubsection{Struktur Tampilan Menu}

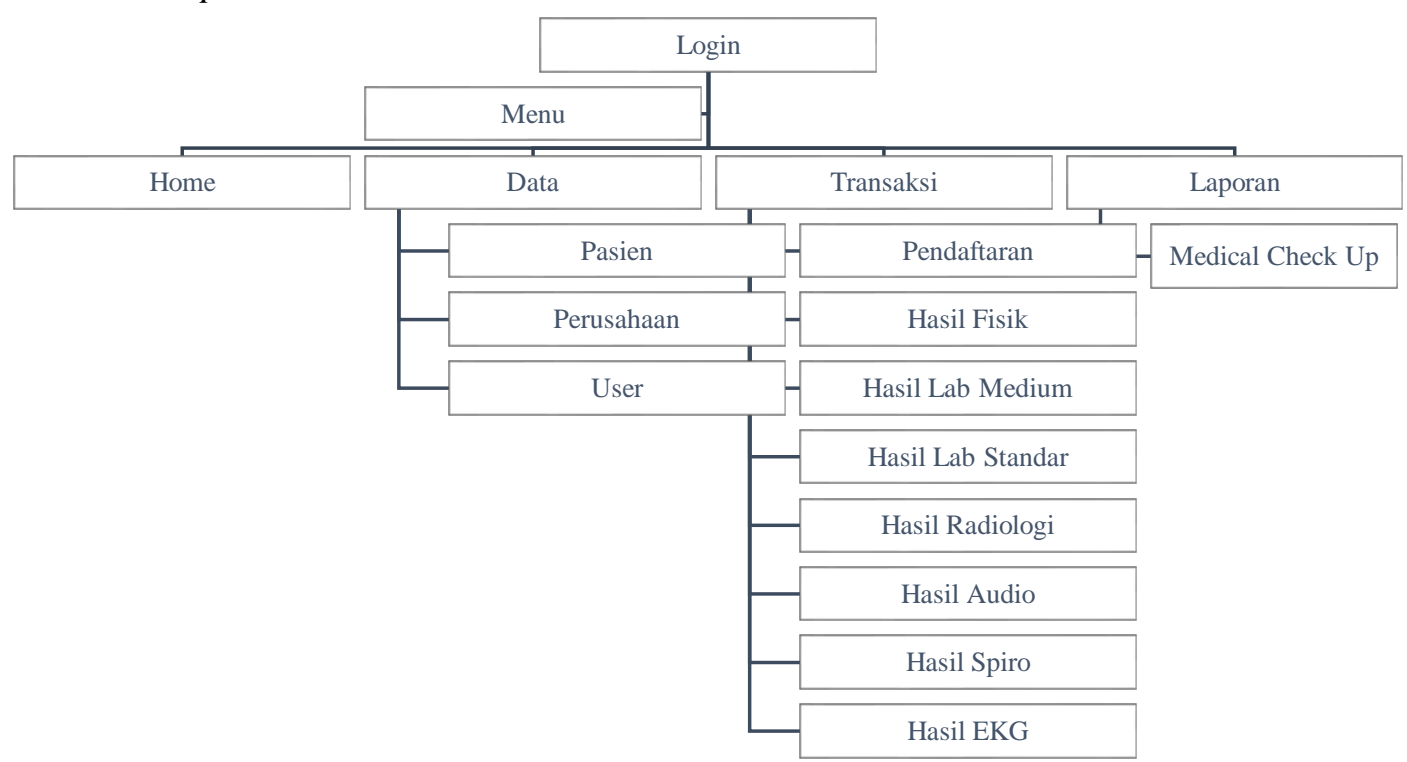

Gambar 5. Struktur Tampilan Menu Aplikasi

\subsubsection{Desain Mockup}

Perancangan desain mockup digunakan untuk menggambarkan sebuah sistem yang akan dibangun. Berikut adalah rancangan tampilan dari sistem informasi laporan hasil pemeriksaan medical check up.

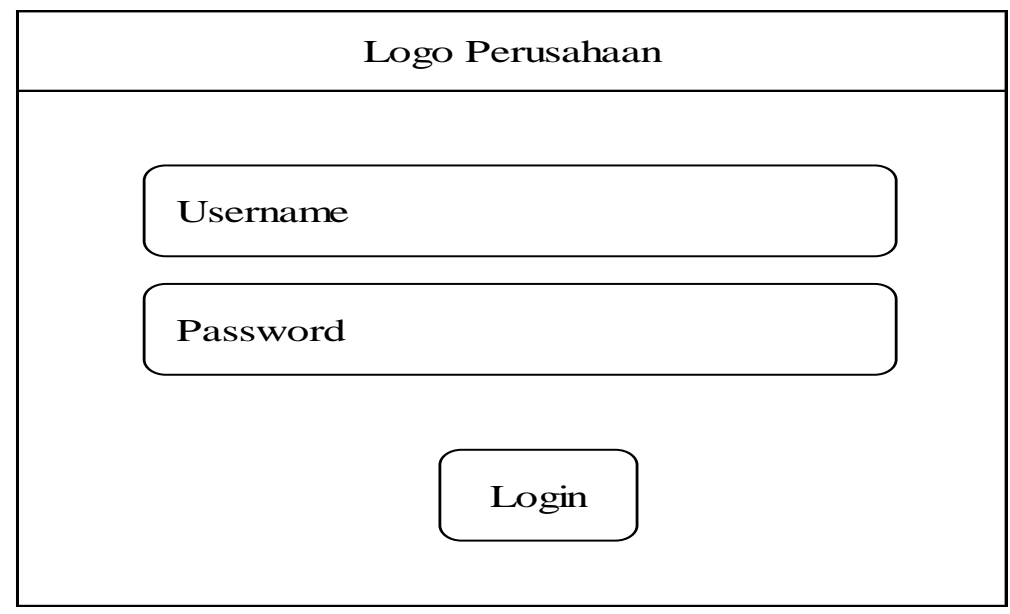

Gambar 6. Form Login 


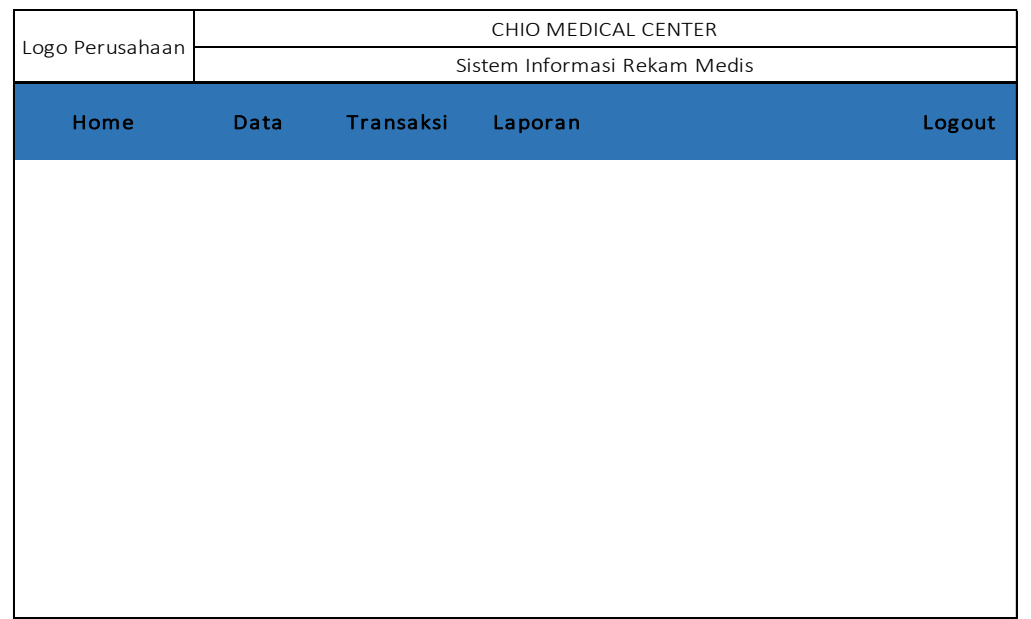

Gambar 7. Tampilan Menu Utama

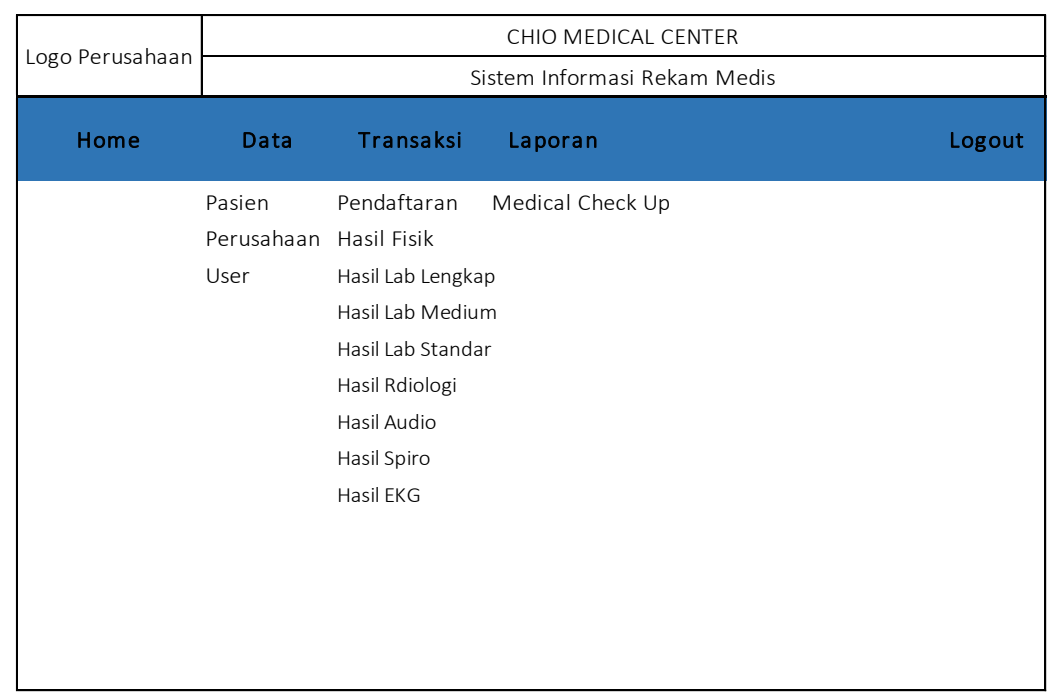

Gambar 8. Tampilan Sub Menu

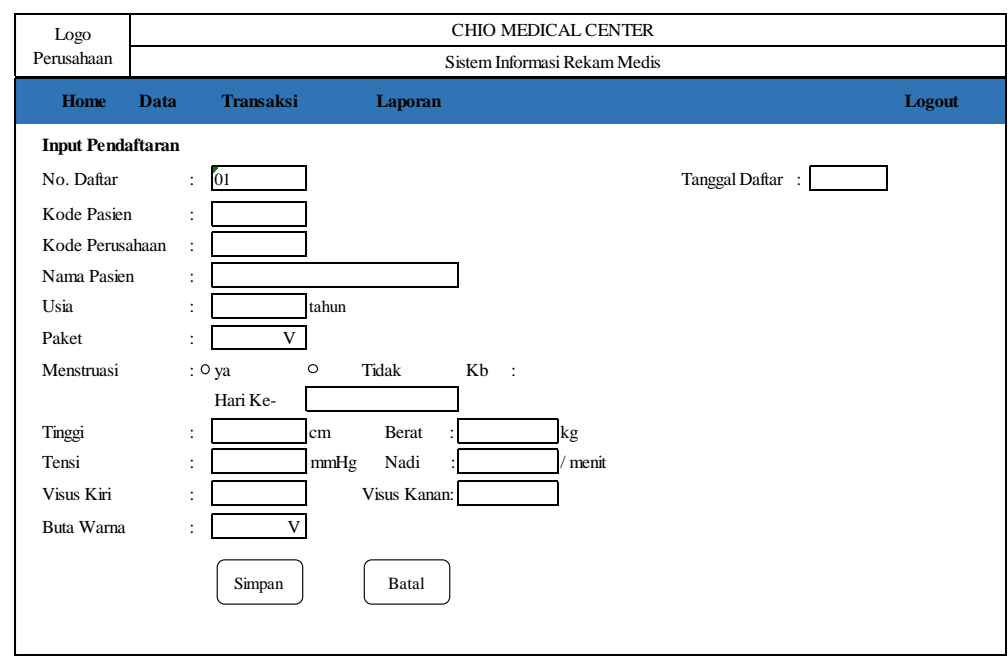

Gambar 9. Tampilan Form Input Pendaftaran 


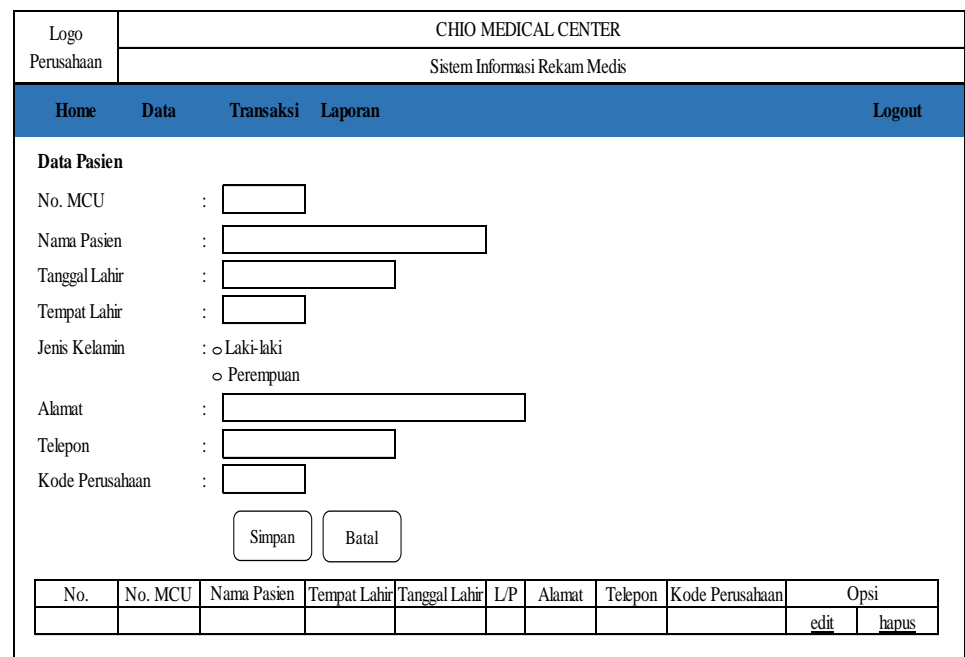

Gambar 10. Form Input Data Pasien

\begin{tabular}{|c|c|c|c|c|c|c|c|}
\hline \multirow{2}{*}{$\begin{array}{c}\text { Logo } \\
\text { Perusahaan }\end{array}$} & \multicolumn{7}{|c|}{ CHIO MEDICAL CENTER } \\
\hline & \multicolumn{7}{|c|}{ Sistem Informasi Rekam Medis } \\
\hline Home & Data & Transaksi & iporan & & & & Logout \\
\hline \multicolumn{8}{|c|}{ Data Perusahaan } \\
\hline \multicolumn{2}{|c|}{ Kode Perusahaan } & P001 & & & & & \\
\hline \multicolumn{8}{|c|}{ Nama Perusahaan } \\
\hline \multicolumn{8}{|l|}{ Alamat } \\
\hline \multicolumn{8}{|l|}{ Telepon } \\
\hline & & Simpan & Batal & & & & \\
\hline \multirow[t]{2}{*}{ No } & Kode & \multicolumn{2}{|c|}{ Nama Perusahaan } & Alamat & No. Telepon & \multicolumn{2}{|c|}{ Opsi } \\
\hline & & & & & & edit & hapus \\
\hline
\end{tabular}

Gambar 11. Form Input Data Perusahaan

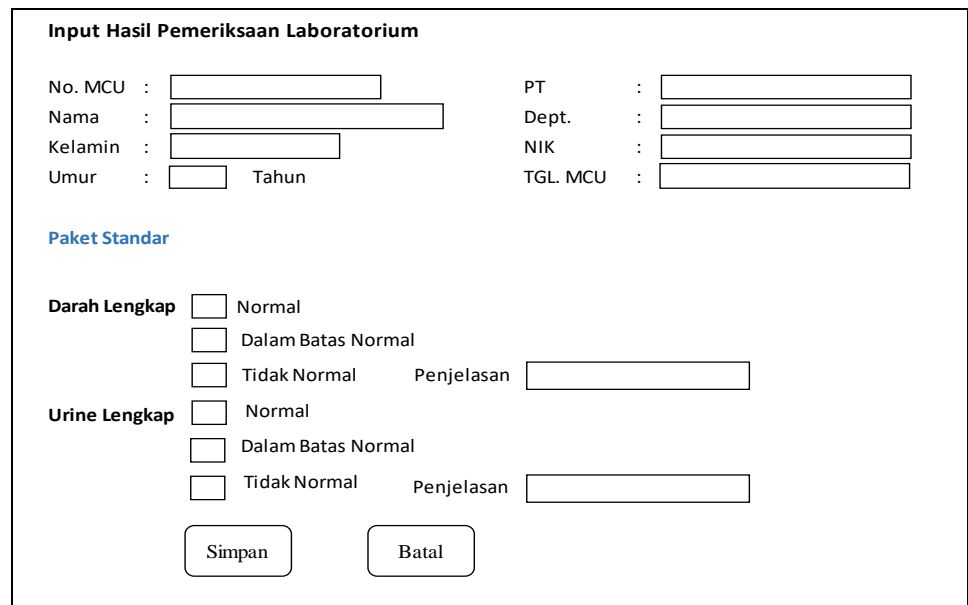

Gambar 12. Form Input Lab Paket Standar 


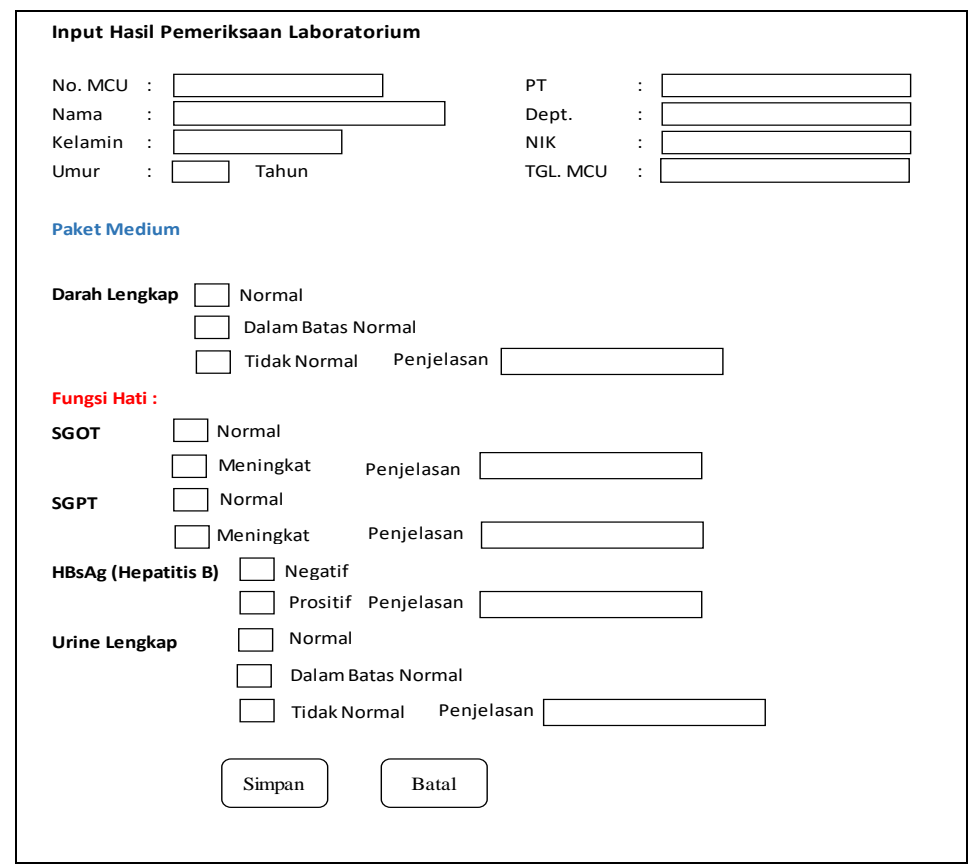

Gambar 13. Form Input Lab Paket Medium

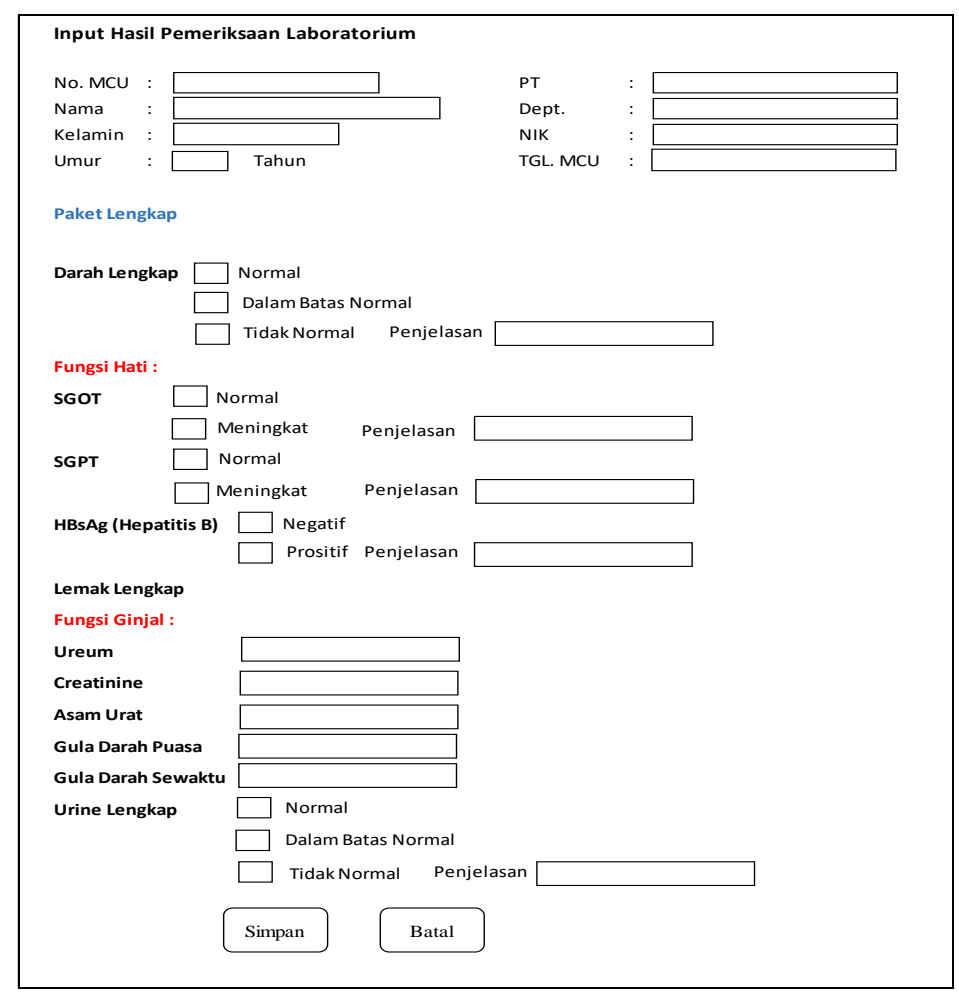

Gambar 14. Form Input Lab Paket Lengkap 


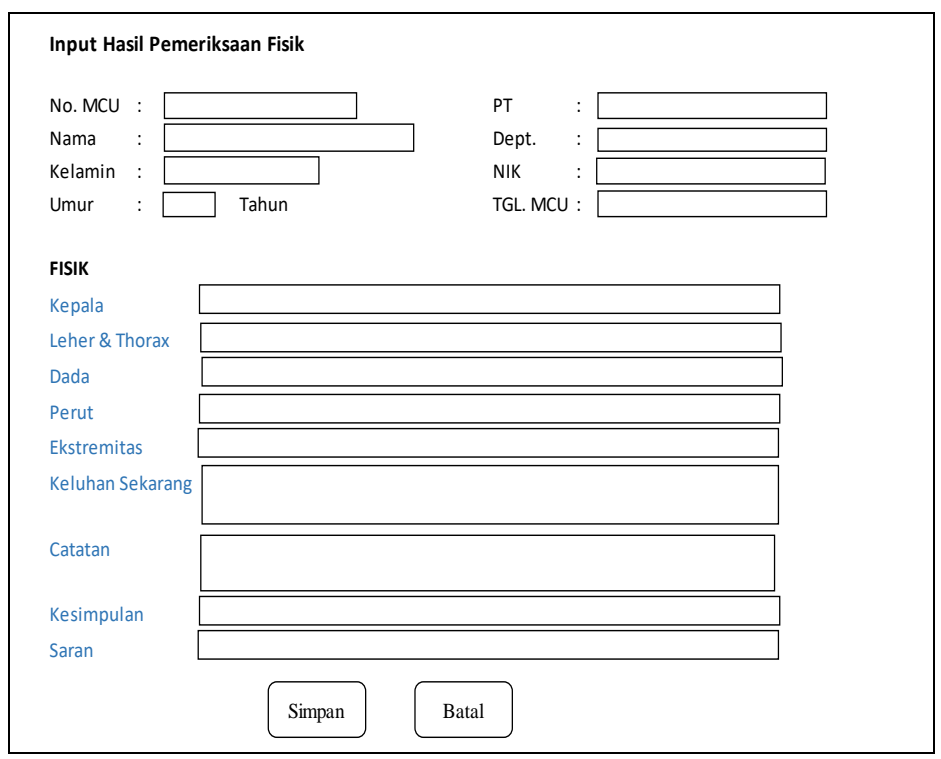

Gambar 15. Form Input Pemeriksaan Fisik

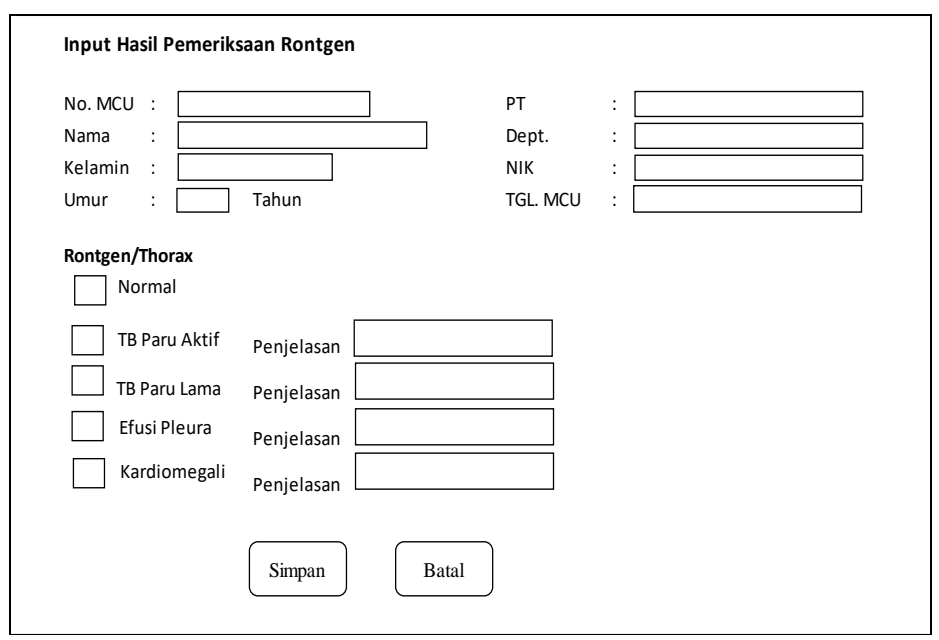

\section{Gambar 16. Form Input Pemeriksaan Radiologi}

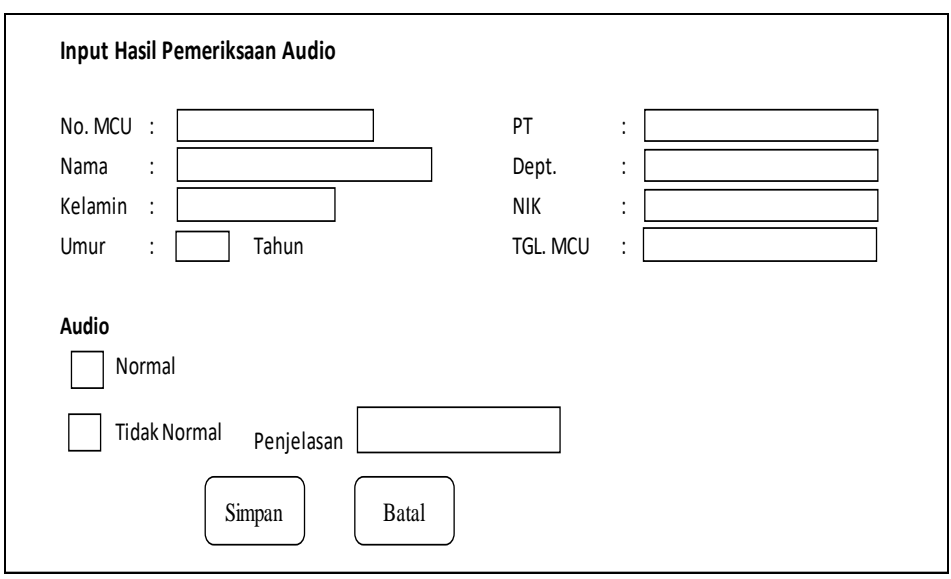

Gambar 17. Form Input Pemeriksaan Audio 


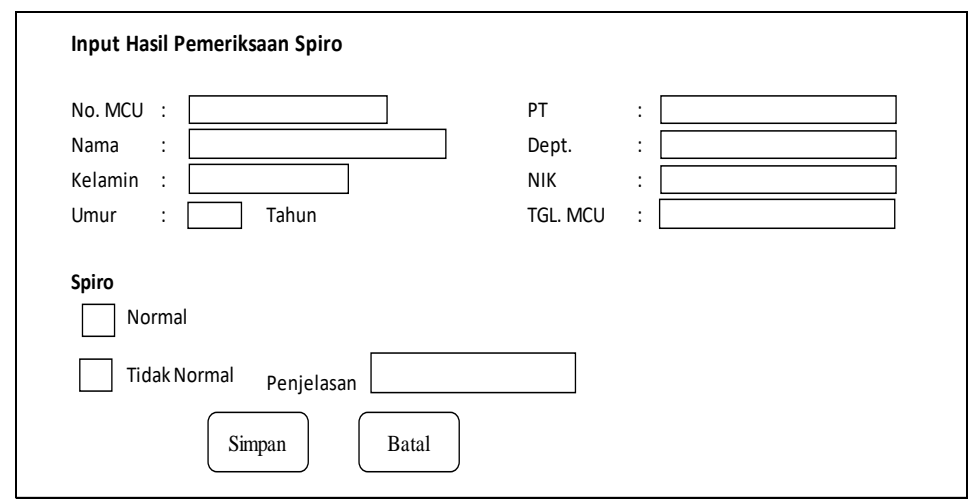

Gambar 18. Form Input Pemeriksaan Spiro

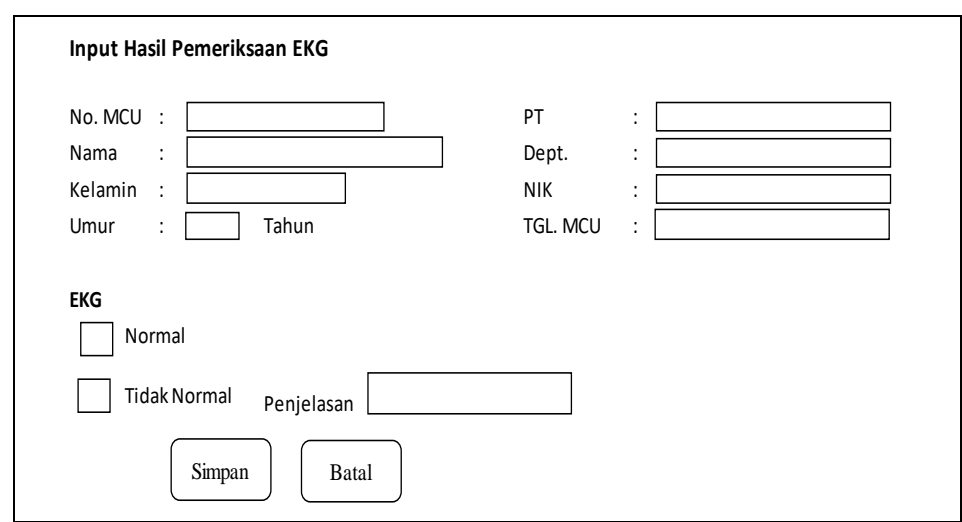

Gambar 19. Form Input Pemeriksaan EKG

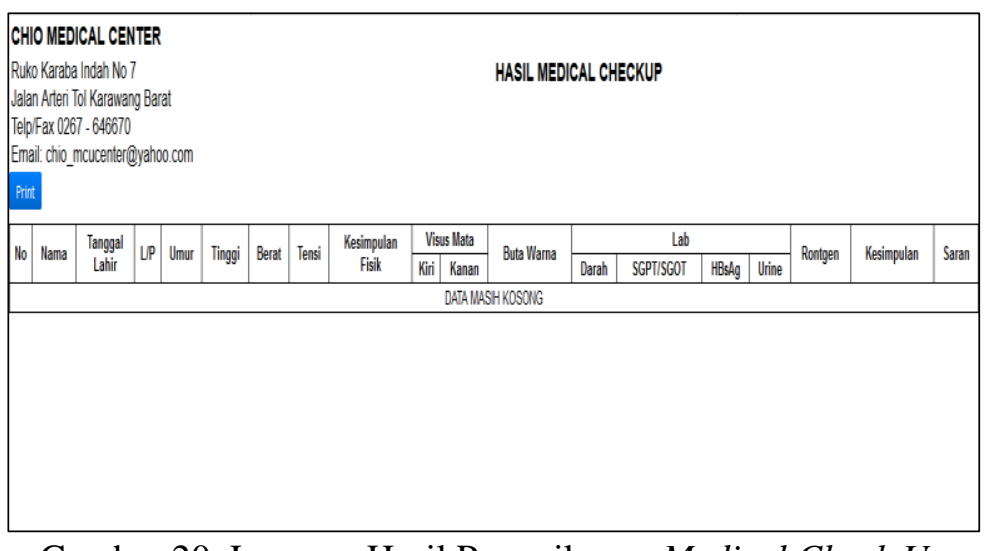

Gambar 20. Laporan Hasil Pemeriksaan Medical Check Up

\section{Kesimpulan dan Saran}

\subsection{Kesimpulan}

Sistem informasi laporan hasil pemeriksaan medical check up dapat memberikan pengaruh yang baik terhadap pengelolaan data medical check up terutama bagi admin dan perusahaan. Pencatatan dan laporan hasil pemeriksaan medical check up di Klinik Chio Medical Center masih menggunakan microsoft word dan microsoft excel sehingga belum terkomputerisasi dengan baik. Berdasarkan permasalahan tersebut, penulis membangun sebuah sistem berbasis web dengan menggunakan database yang berguna untuk menyimpan hasil medical check up yang relative banyak sehingga penyimpanan menjadi terstruktur. Sistem informasi laporan hasil pemeriksaan medical check up diharapkan dapat membantu petugas klinik dalam pencatatan data dan pembuatan laporan menjadi lebih cepat, dan akurat serta dapat meminimalisir kesalahan yang mungkin terjadi pada saat melakukan pengelohan data klinik.

\subsection{Saran}

Sistem informasi rekam medis berbasis web ini belumlah sempurna. Penulis menyadari masih banyak kekurang yang terdapat pada sistem ini, oleh kerena itu penulis berharap penelitian ini dapat dilanjutkan untuk 
mendapatkan hasil yang lebih baik dari sebelumnya. Berikut adalah saran yang dapat diberikan penulis untuk pengembangan dari sistem informasi rekam medis berbasis web, yaitu:

a. Membuat back up data untuk menjaga kemungkinan rusaknya data ketika perangkat lunak mengalami masalah.

b. Memantau efektifitas dan efesiensi program untuk pengembangan program selanjutnya guna mengantisipasi kebutuhan sistem dimasa yang akan datang.

\section{References}

[1] Yulistyawan, "Sistem Penjadwalan Medical Check Up PT. PAL Indonesia-Ujung Surabaya Dengan Menggunakan Teknologi Berbasis Web," Semin. Nas. K3 PPNS 2017, vol. 1, no. 1, pp. 1-5, 2017.

[2] I. Gunawan, F. Agushybana, and M. I. Kartasurya, "Perancangan Sistem Informasi Medical Check Up Guna Mempercepat Pelayanan MCU di RSUD Brebes," J. Kesehat., vol. 8, no. 1, pp. 39-54, 2020, doi: 10.24252/kesehatan.v7i2.54.

[3] N. Oktaviani, I. M. Widarta, and Nurlaily, "Sistem Informasi Inventaris Barang Berbasis Web Pada Smp Negeri 1 Buer," J. JINTEKS, vol. 1, no. 2, pp. 160-168, 2019.

[4] B. J. Kaleb, V. P. . Lengkong, and R. N. Taroreh, "Penerapan Sistem Informasi Manajemen Dan Pengawasannya Di Kantor Pelayanan Pajak Pratama Manado," J. EMBA J. Ris. Ekon. Manajemen, Bisnis dan Akunt., vol. 7, no. 1, pp. 781-790, 2019, doi: 10.35794/emba.v7i1.22555.

[5] P. Sutopo, D. Cahyadi, and Z. Arifin, "Sistem Informasi Eksekutif Sebaran Penjualan Kendaraan Bermotor Roda 2 di Kalimantan Timur Berbasis Web," Inform. Mulawarman J. Ilm. Ilmu Komput., vol. 11, no. 1, pp. 23-28, 2016, doi: 10.30872/jim.v11i1.199.

[6] D. Gusmaliza, "PERANGKAT LUNAK BANTU ADMINISTRASI KEUANGAN SEKOLAH TINGGI TEKNOLOGI PAGAR ALAM DENGAN PHP DAN MySQL,” J. Ilm. Betrik, vol. 10, no. 01, pp. 28-37, 2019.

[7] T. Rahmasari, "Perancangan Sistem Informasi Akuntansi Persediaan Barang Dagang Pada Toserba Selamat Menggunakan Php Dan Mysq1,” @is Best [Accounting Inf. Syst. Inf. Technol. Bus. Enterp., vol. 4, no. 1, pp. 411425, 2019, doi: 10.34010/aisthebest.v4i1.1830.

[8] S. Ali and A. Ambarita, "SISTEM INFORMASI DATA BARANG INVENTARIS BERBASIS WEB PADA KEJAKSAAN NEGERI TERNATE,” Indones. J. Inf. Syst. Sist., vol. 1, no. 1, pp. 31-38, 2016.

[9] I. K. Juliany, M. Salamuddin, and Y. K. Dewi, "Perancangan Sistem Informasi E-Marketplace Bank Sampah Berbasis Web," Semin. Nas. Teknol. Inf. dan Multimed. 2018, pp. 19-24, 2018, doi: 10.1111/j.13652621.2009.02155.x.

[10] I. Samsudin and M. Muslihudin, "Implementasi Web Government Dalam Meningkatkan Potensi Produk Unggulan Desa Berbasis Android," Jtksi, vol. 1, no. 2, pp. 10-16, 2018.

[11] A. A. Sofyan, A. Budiman, and Dendi, "Pengembangan Sistem Kalkulasi Inefisiensi Pelapis Pada Produk Keramik Berbasis Web Di PT Satyaraya Keramindoindah,” J. Sisfotek Glob., vol. 9, no. 1, pp. 75-80, 2017.

[12] A. Kadir, Pengenalan Sistem Informasi Edisi Revisi. Yogyakarta: Andi Offset, 2014. 